\title{
DENDROBIOLOGY
}

2015, vol. 74, 13-24

http://dx.doi.org/10.12657/denbio.074.002

\author{
Hanna Dahm, Anna Joanna Brzezińska, \\ Wioletta Wrótniak-Drzewiecka, Patrycja Golińska, \\ Henryk Różycki, Mahendra Rai
}

\section{Myxobacteria as a potential biocontrol agent effective against pathogenic fungi of economically important forest trees}

Received: 14 November 2014; Accepted: 30 March 2015

\begin{abstract}
The broad biocontrol properties of myxobacteria (mainly members of the genera Corallococcus and Myxococcus) isolated from forest soils against main fungal pathogens of pine seedlings were estimated. Among the myxobacterial strains studied (in vivo tests), the strongest antagonism towards fungi was noticed for the strains of the species Myxococcus virescens Thaxter and Corallococcus exiguus Reichenbach. They inhibited the fungal growth within the range 38-63\%. The strongest inhibitory reaction towards $C y$ lindrocarpon destructans (Zinssm.) Scholten was observed. A predominating part of myxobacteria (22 from among 30) inhibited the growth of Rhizoctonia solani Kühn. Myxobacteria suppressed any pathogenic action of Rhizoctonia solani (strain 411) towards Scots pine seedlings (in vitro tests). They produced extracellular (but not intracellular) acidic and neutral proteinases. None of the myxobacterial strain under examination produced chitinases. The $57 \%$ of the myxobacterial strains studied produced siderophores.

The numbers of myxobacterial strains, obtained from under forest trees were in the following order: Betula pendula Roth. > Pinus sylvestris L. > Alnus glutinosa Gaertn. = Quercus robur L.

The results gained in present work have proved potential use of myxobacteria as biocontrol agents against Rhizoctonia solani, common fungal pathogen of pine seedlings.
\end{abstract}

Additional key words: Myxobacteriales, antifungal properties, enzymatic activity, siderophores, Pinus sylvestris

Addresses: H. Dahm, A.J. Brzezińska, W. Wrótniak-Drzewiecka, P. Golińska, H. Różycki, Department of Microbiology, Nicolaus Copernicus University, Lwowska 1, 87-100 Toruń, Poland, e-mail: dahm@umk.pl M. Rai, Department of Biotechnology, Sant Gadge Baba Amravati University, Amravati - 444 602, Maharashtra, India 


\section{Introduction}

Myxobacteria are unique among bacteria due to their complicated multicellular morphogenesis and behavior. They have been isolated from a variety of environment and substrates particularly from soil of tropical to temperate regions (Reichenbach and Dworkin 1981; Reichenbach 1999; Shimkets et al. 2006). They inhabit the topsoil, and population estimates range from 2,000 to 450,000 per gram of soil (Dawid 2000). However, almost nothing is known about their presence in forest soil, but it is supposed that fewer species are yielded from acid forest than that from agricultural soil.

Myxobacteria are micropredators of various microorganisms including Gram-positive and Gram-negative bacteria (Morgan et al. 2010) as well as fungi (Bull et al. 2002). Few studies have evaluated interaction between myxobacteria and plant pathogens (Hocking and Cook 1972; Homma 1984; Kerk et al. 2013) and the role of myxobacteria in plant health remains unexplored. Antibiotics and enzymes produced by myxobacteria kill microorganisms and lyse cells from which biomacromolecules are destroyed. Antibiotics and enzymes degrade structural cell macromolecules such as polysaccharides, proteases and nucleases.

Predatory capabilities of myxobacteria indicated that they are able to enhance plant health by inhibiting the growth of fungal plant pathogens (Bull et al. 2002). The myxobacteria act as biocontrol agents against pathogens by competition, antibiosis and parasitism. Activity is not restricted to only one of these. In fact, efficient biocontrol agent may affect pathogens by combination of mechanisms (Chet and Inbar 1994). Microorganisms compete with each other for food and essential elements in the soil. Kloepper et al. (1980) demonstrated the importance of siderophores in the mechanism of biological control, which mediate the limited amount of iron in the rhizosphere, deprive pathogens of iron and suppress their growth.

Some authors (Raheman et al. 2011; Sunkar and Nachiyar 2012) observed greater antibacterial and antifungal activity of silver nanoparticles. Silver nanoparticles preferably attack the respiratory chain, cell division finally leading to cell death (Rai et al. 2009). Our studies (Wrótniak-Drzewiecka et al. 2014) showed bactericidal activity of silver nanoparticles produced by Myxococcus virescens Thaxter.

The aim of the present work was: (i) identification of strains of myxobacteria isolated from forest soils, (ii) analyze the chosen isolates to produce some enzymes degrading macromolecules that participate in the destruction of cells pathogen, (iii) detection of ability to produce siderophores, (iv) determination of myxobacteria as biocontrol agent of plant pathogenic fungi.

We hypothesized that myxobacteria isolated from acidic soil may be a biocontrol agent of the main pathogenic fungi of pine seedlings such as Rhizoctonia solani, Fusarium oxysporum, F. culmorum and Cylindrocarpon destructans.

\section{Material and Methods}

\section{Isolation of myxobacteria strains from the upper layer of soils (depth $10 \mathrm{~cm}$ )}

The myxobacteria were isolated from acidic soils under different forest trees: Pinus sylvestris L., Betula pendula Roth, Alnus glutinosa Gaertn., Quercus robur L. The soil samples were collected from a mixed forest in the Dobrzejewice forest inspectorate, Bielawy forest district in Torun (Lat 53 $01^{\prime} 46^{\prime \prime}$ Long 18 $42^{\prime} 24^{\prime \prime}$; Lat $53^{\circ} 01^{\prime} 27^{\prime \prime} \mathrm{N}$ Long $18^{\circ} 42^{\prime} 28^{\prime \prime} \mathrm{E}$ and Lat $53^{\circ} 02^{\prime} 01^{\prime \prime}$ $\mathrm{N}$ Long $18^{\circ} 42^{\prime} 59^{\prime \prime} \mathrm{E}$, respectively) and from alkaline soil under non forestry tree Salix viminalis L. in Torun (Lat 5301'59" N Long 1855'81") according to Reichenbach and Dworkin method (1981). As a source of isolation of myxobacteria - the basket willow ( $\mathrm{Sa}$ lix viminalis) was included, which is non-forest tree, but considering its soil pH (7.94), it forms a completely different habitat than acidic forest soils.

The trees grew on sandy soils with $\mathrm{pH}=4.30(B$. pendula), 4.22 (P. sylvestris), 5.05 (A. glutinosa), 4.28 (Q. robur), and 7.94 (S. viminalis).

For myxobacteria isolation small pieces of wet soil were put on the filter paper placed on the surface of Vy/2 agar in Petri dishes. The medium were supplemented with cycloheximide and nystatin (each at $100 \mu \mathrm{g} \mathrm{ml}^{-1}$ ) and penicillin $\left(50 \mu \mathrm{g} \mathrm{ml}^{-1}\right)$.

\section{Identification of myxobacteria strains}

Sixty one myxobacterial strains (7 isolated from pine soil, 11 from birch, 31 from willow and 6 from each alder and oak soil) were identified using morphological and biochemical methods.

Morphological and biochemical methods: they comprised studies on the production of the slime, morphology of swarm colony, fruiting bodies, vegetative cells and myxospores as well as fluorescence under UV radiation (Reichenbach and Dworkin 1981; Reichenbach 2005). Biochemical tests comprised the ability to hydrolyse starch and aesculin (Lang and Stackebrandt 2009).

For further analysis thirty strains isolated from forest soils were chosen.

Molecular identification: Genomic DNA was extracted from the representative isolates using a GenElute $^{\mathrm{TM}}$ Bacterial Genomic Kit (Sigma), according to 
the instructions of the manufacturer. The 16S rRNA genes were amplified using the universal primers p10-30f (5'-GAGTTTGATC-CTGGCTCA-3') and p1500r (5'-AGAAAGGAGGTGATCCAGCC-3') under the following conditions: $1 \mu$ l DNA template (final concentration $100 \mathrm{ng} \mathrm{ml}^{-1}$ ), $10 \mu \mathrm{l} 10 \times \mathrm{DNA}$ polymerase buffer with $25 \mathrm{mM} \mathrm{MgCl}_{2}$ (Roche), $20 \mu \mathrm{l}$ of UTPs (10 mM stock mixture, Roche) $1 \mu \mathrm{l}$ of each primer ( $5 \mathrm{mM}$ stock solution) and $0.4 \mu$ l polymerase (5 U, Roche). The amplified products were separated by electrophoresis, purified with a Qiaquick Gel Extraction Kit (Qiagen) and directly sequenced using a ABI Prism "Big Dye" Terminator Cycle Sequencing Kit (Applied Biosystems) by the DNA Sequencing and Oligonucleotide Synthesis Laboratory of the Institute of Biochemistry and Biophysics, Polish Academy of Science in Warsaw. Nearly complete 16S rRNA gene sequences of the isolates $(\sim 1400$ nucleotides [nt]) were determined and compared with corresponding sequences of the most closely related type strains using the EzTaxon server (Kim et al. 2012).

\section{Antagonistic properties of isolated myxobacteria against fungal pathogens of pine seedlings}

\section{In vitro test}

For this study, 30 strains of myxobacteria and four common and main pathogenic fungi of pine seedlings such as Rhizoctonia solani Kühn, Fusarium oxysporum Schlecht, F. culmorum (W.G. Smith) Sacc. and Cylindrocarpon destructans (Zinssm.) Scholten were used. Pathogenic fungi were obtained from Department of Forest Phytopatology, Poznan University of Life Sciences.

Tests were performed in mixed cultures of myxobacteria and fungi in Petri dishes with dCTA medium according to Bull et al. (2002), all in three replicates. The results of mutual interaction between the myxobacteria and the fungi were observed for a four weeks. The radius of the fungal colony in the fungal control culture (without myxobacteria) and mixed cultures with myxobacteria were measured daily. The degree of antagonism of myxobacteria against fungi was expressed as an index of per cent inhibition, which was calculated according to the formula:

$\%$ inhibition $=1$-(fungal radius in a mixed culture with myxobacteria/ fungal radius in control colony) $\times 100$

For inoculation of seedlings (in vivo tests) three strains of myxobacteria (Corallococcus exiguus B5 and D4 and Myxococcus virescens S5) were chosen. These strains showed the high degree of inhibition of pathogenic fungi in vitro studies. Fusarium culmorum was omitted because a low number of myxobacterial strains influenced the growth of this fungus in vitro.

\section{In vivo test}

Pinus sylvestris (L) seedlings were grown from certified seeds obtained from the forest nursery in Klosnowo, near Chojnice. The used culture media was soil from under Scots pine ( $\mathrm{pH} 4.12)$. Cultures of seedlings were performed in sterile soils (autoclaved for three consecutive days). The seedlings (from sterile seeds sterilized with $30 \% \mathrm{H}_{2} \mathrm{O}_{2}$ for 20 min) were grown in a culture chamber at $22 \pm 4^{\circ} \mathrm{C}$ in the light of sodium lamps with an illumination of 7,000 lux (approx. $100 \mu \mathrm{mol} \mathrm{m}{ }^{-2} \mathrm{~s}^{-1} \mathrm{PAR}$ - photosynthetically active radiation) 16 hours and 8 hours in the dark.

Suspensions of different myxobacterial strains were prepared $\left(10^{8}\right.$ cells $\left.\mathrm{ml}^{-1}\right)$ from their culture in the MD1 medium (Behrens et al. 1976) for 7 days. Fungi (Rhizoctonia solani, Fusarium oxysporum and $\mathrm{Cy}$ lindrocarpon destructans) were grown in liquid Czapek-Dox medium (Difco) for 7 days.

The fungal suspension for seedling inoculation was prepared by culture centrifugation for $10 \mathrm{~min}$ at $3500 \mathrm{x}$ g. The mycelium was washed twice with sterile distilled water, then suspended in $30 \mathrm{ml}$ of sterile distilled water and homogenized. Subsequently, each three-week old pine seedling (ten replicates per experimental variant) was inoculated with $1 \mathrm{ml}$ of fungal inoculum. The seedlings not inoculated with any microorganisms, inoculated either with the appropriate fungus or myxobacterium were used as negative and positive controls, respectively. The tested seedlings were inoculated with two microorganisms - an appropriate pathogenic fungus (Cylindrocarpon destructans, Fusarium oxysporum or Rhizoctonia solani) and myxobacterium (Myxococcus virescens or Coralococcus exiguus).

After 19 weeks duration of experiment, reisolation of myxobcteria from rhizosphere of pine seedlings and the morphological analysis of the seedlings were performed by measuring root and shoot length, as well as dry root and shoot mass. For dry mass estimation the roots and shoots of the pine seedlings were dried at $80^{\circ} \mathrm{C}$ for 6 hours.

Reisolation myxobacteria from rhizosphere of pine seedlings were performed by washing roots with sterile distilled water and inoculation with suspension gained on $\mathrm{Vy} / 2$ agar in Petri dishes plates. Identification of myxobacteria based on morphological properties and analysis of 16S rRNA gene sequences were carried out as described previously. 


\section{Enzymatic activity studies}

\section{Chitinolytic activity}

Chitynolytic enzyme production of myxobacterial strains were performed in the test tubes containing agar medium (according to Lingappa and Lockwood $1962)$ with colloidal chitin $(0.5 \%, \mathrm{w} / \mathrm{v})$ after inoculation with isolates. Tests were carried out in three replicates. After 18 days of incubation at $30^{\circ} \mathrm{C}$, the depth of the chitin hydrolysis zone was measured.

\section{Proteolytic activity}

\section{a) Preliminary studies}

Myxobacterial strains were grown in the Petri dishes with Rodina (1968) medium containing gelatin $(4 \%, w / v)$, all in three replicates. After 7 days of incubation at $30^{\circ} \mathrm{C}$ the cultures were flooded with Frazier's reagent for 5 minutes. The width of protein hydrolysis zone was measured.

b) The activity of acid (EC 3.4.23) and neutral (EC 3.4.24) proteinases

The activity of proteinases was determined according to Hazen (1965). Microorganisms were grown for 10 days in liquid medium according to Whooley (1983) using $5 \mathrm{~g} / \mathrm{dm}^{3}$ of both sodium caseinate (Sigma) and yeast extract (Difco).

Proteinase activity was determined from the post-culture liquid of myxobacteria (exocellular) or intracellular, all in nine replicates.

The reaction mixtures were $250 \mu \mathrm{l}$ post-culture supernatant and $250 \mu \mathrm{l} 2 \%$ Azocasein (Sulfanilamide Azocasein, Sigma) in $0.2 \mathrm{M}$ acetate buffer $\mathrm{pH} 4.5$ (for acid proteinases) or $250 \mu \mathrm{l} 2 \%$ Azocasein (Sulfanilamide Azocasein, Sigma) in $0.2 \mathrm{M}$ Tris- $\mathrm{HCl}$ buffer $\mathrm{pH} 7.5$ (for neutral proteinases). The reaction mixture were then placed in a water bath. After 4 hours of incubation at $37^{\circ} \mathrm{C}$, the reaction was stopped by adding $800 \mu \mathrm{l} 7 \%$ perchloric acid $\left(\mathrm{HClO}_{4}\right)$. Then the samples were centrifuged at $10000 \mathrm{rpm}$ for $10 \mathrm{~min}$ at $4^{\circ} \mathrm{C}$. One $\mathrm{ml}$ of the supernatant was added to 150 $\mu \mathrm{l}$ of $10 \mathrm{~N} \mathrm{NaOH}$ and the proteolytic activity was determined spectrophotometrically at $440 \mathrm{~nm}$. The one $\mu$ mol tyrosine per minute released from the substrate was taken as the unit of acid and neutral proteinase activity.

Intracellular protease activity after cells disintegration was studied using the method given above. Before disintegration, bacterial cells were centrifuged at $4^{\circ} \mathrm{C}$ and washed twice with distilled water. Thereafter, bacterial pellet was disintegrated using Sonic Ruptor 250 OMNI at $20 \mathrm{KHz}$ for 10 minutes.

\section{Siderophores production}

Siderophores were detected using plate culture method on CAS agar (Chrome Azurol S Agar) according to Alexander and Zuberer (1991). Presence of siderophores was noticed on the basis of the agar medium color change from bluish-green to the yellow or orange one - due to iron removal from $\mathrm{Fe}$-dye complex by the siderophores studied. Tests were carried out in three replicates.

\section{Statistical analysis}

Data were analyzed using analysis of variance in the Statistica 5.1 package. Significance of differences between means were evaluated using Newman-Keuls multiple range test and Student's t-test $(\mathrm{p}=0.05)$.

\section{Results}

\section{Identification of isolated myxobacteria}

Myxobacteria were isolated from all the soil samples studied (Table 1). A total of 61 strains were isolated, which were identified to the genus/species level on the basis of their morphological and physiological properties, and on the basis of taxonomical keys by Reinchenbach and Dworkin (1981), Reinchenbach (2005) and Lang and Stackebrandt (2009). When comparing the source of isolation, the largest number of strains was isolated from under the willow, comprising $50.82 \%$ of total number of strains. Myxobacteria were less numerous in acidic

Table 1. Number and percentage genus/species of myxobacteria isolated from soil from under pine, birch, oak, alder, willow based on taxonomic keys Reichenbach and Dworkin (1981), Reichenbach (2005) and Lang and Stackebrandt (2009)

\begin{tabular}{|c|c|c|c|c|c|c|c|c|c|c|c|c|c|}
\hline \multirow{3}{*}{ No. } & \multirow{3}{*}{ Bacterial genus/ species } & \multicolumn{12}{|c|}{ Soil from under } \\
\hline & & \multicolumn{2}{|c|}{ Pine } & \multicolumn{2}{|c|}{ Birch } & \multicolumn{2}{|c|}{ Oak } & \multicolumn{2}{|c|}{ Alder } & \multicolumn{2}{|c|}{ Willow } & \multicolumn{2}{|c|}{ Total } \\
\hline & & No. & $\%$ & No. & $\%$ & No. & $\%$ & No. & $\%$ & No. & $\%$ & No. & $\%$ \\
\hline 1. & Corallococcus exiguus & 3 & 42.86 & 6 & 54.55 & 4 & 66.67 & 5 & 83.33 & 7 & 22.58 & 25 & 40.98 \\
\hline 2. & Myxococcus sp. & 1 & 14.29 & 1 & 9.09 & 0 & 0 & 0 & 0 & 11 & 35.48 & 13 & 21.31 \\
\hline 3. & Corallococcus coralloides & 0 & 0 & 1 & 9.09 & 0 & 0 & 1 & 16.67 & 5 & 16.13 & 7 & 11.47 \\
\hline 4. & Myxococcus virescens & 2 & 28.57 & 1 & 9.09 & 2 & 33.33 & 0 & 0 & 1 & 3.23 & 6 & 9.84 \\
\hline 5. & Polyangium fumosum & 0 & 0 & 1 & 9.09 & 0 & 0 & 0 & 0 & 3 & 9.68 & 4 & 6.56 \\
\hline 6. & Sorangium cellulosum & 0 & 0 & 0 & 0 & 0 & 0 & 0 & 0 & 4 & 12.90 & 4 & 6.56 \\
\hline 7. & Archangium gephyra & 1 & 14.29 & 0 & 0 & 0 & 0 & 0 & 0 & 0 & 0 & 1 & 1.64 \\
\hline 8. & Jahnia thaxteri & 0 & 0 & 1 & 9.09 & 0 & 0 & 0 & 0 & 0 & 0 & 1 & 1.64 \\
\hline Numbe & / \% of strains studied & 7 & $\sim 100$ & 11 & 100 & 6 & 100 & 6 & 100 & 31 & 100 & 61 & 100 \\
\hline
\end{tabular}


soils ( $\mathrm{pH}$ 5.05-4.22), under birch (Betula pendula) (18.03\%), pine (Pinus sylvestris) $(11.47 \%)$, oak (Quercus robur) and alder (Alnus glutinosa) (9.84\% each). Based on morphological and biochemical identification, members of the suborder Cystobacterineae were predominating among myxobacteria studied. Over half of them belonged to the genus Corallococcus with $C$. exiguus, as a predominating species. The genus Myxococcus was occurred less often. Majority of its members were not identified to the species level (21.31\%). However, species identified as Myxococcus virescens comprised $9.84 \%$. Among the members of suborder Cystobacterineae, one strain was identified as Archangium gephyra Jahn. Myxobacteria of the order Sorangineae were less numerous than those of the suborder Cystobacterineae and comprised $14.76 \%$ of the total number of the strains isolated. Among the members of Sorangineae, Polyangium fumosum Krzemieniewska and Krzemieniewski and Sorangium cellulosum (Brockman) Reichenbach were predominating species. One strain was identified as Jahnia thaxteri (Jahn) Reichenbach. The most diverse species com-

Table 2. Strains of myxobacteria used in the present study

\begin{tabular}{cc}
\hline Symbol of strains & Myxobacterial species \\
\hline S1 & Myxococcus virescens \\
S2 & Corallococcus exiguus \\
S3 & Corallococcus exiguus \\
S4 & Corallococcus exiguus \\
S5 & Myxococcus virescens \\
S6 & Myxococcus fulvus \\
S7 & Archangium gephyra \\
B1 & Corallococcus exiguus \\
B2 & Corallococcus exiguus \\
B3 & Corallococcus exiguus \\
B4 & Corallococcus exiguus \\
B5 & Corallococcus exiguus \\
B6 & Corallococcus exiguus \\
B7 & Myxococcus virescens \\
B8 & Polyangium fumosum \\
B9 & Jahnia thaxteri \\
B10 & Myxococcus fulvus \\
B11 & Corallococcus coralloides \\
D1 & Corallococcus exiguus \\
D2 & Corallococcus exiguus \\
D3 & Corallococcus exiguus \\
D4 & Corallococcus exiguus \\
D5 & Myxococcus virescens \\
D6 & Myxococcus virescens \\
O1 & Corallococcus exiguus \\
O2 & Corallococcus exiguus \\
O3 & Corallococcus exiguus \\
O4 & Corallococcus exiguus \\
O5 & Corallococcus coralloides \\
O6 & Corallococcus exiguus \\
\hline & S1- \\
\hline
\end{tabular}

Explanations: S1-S7 strains isolated from pine tree soil, B1-B11 strains isolated from birch tree soil, D1-D6 strains isolated from oak tree soil, O1-O6 strains isolated from alder tree soil. position among myxobacteria from under birch and non-forest tree - willow was noted (6 taxons). The least diverse habitat was soil under oak and alder (2 taxons) (Table 1 and 2).

For further studies only strains isolated from forest soils were chosen and identified based on 16S rRNA gene sequences. Nearly complete 16S rRNA gene sequences of the isolates were determined. Myxobacterial strains shared a 16S rRNA gene similarity of between $99.0-100 \%$ with the closest phylogenetic neighbours. Results of molecular identification based on analysis of 16S rRNA gene sequences confirmed previously identification results obtained by morphological and biochemical studies. Moreover, two strains (S6 and B10) previously identified as a Myxococcus sp. were identified to species level as a Myxococcus fulvus based on analysis of 16S rRNA gene sequences.

All isolates of Corallococus sp. as well as Archangium gephyra and Polyangium fumosum were able to starch and aesculin hydrolysis but none of Myxococcus sp.

Jahnia thaxteri hydrolysed aesculin but not starch.

\section{In vitro effect of myxobacteria on fungi pathogenic to pine seedlings}

Among the myxobacterial strains studied, the strongest antagonism towards fungi was noticed for the strains of Myxococcus virescens and Corallococcus exiguus. They inhibited the fungal growth within the range $38-63 \%$. The strongest inhibitory reaction towards Cylindrocarpon destructans was observed. All the myxobacterial strains used in this study inhibited the growth of the above mentioned fungus. The lowest number of myxobacterial strains exerted an inhibitory action towards Fusarium culmorum. Although only 9 strains from among 30 studied ones inhibited the growth of the above mentioned fungus, some of them revealed $50 \%$ high inhibition rate. Majority of myxobacteria (22 from among 30 ) inhibited the growth of Rhizoctonia solani. Five of them retarded the growth of the above mentioned fungus at a rate exceeding 50\% (Fig. 1 A,B,C,D). Results of our studies have revealed highest antifungal activity by Myxococcus virescens, a strain isolated from soil under pine. M. virescens inhibited the growth of Cylindrocarpon destructans and Rhizoctonia solani at rates above $70 \%$, Fusarium oxysporum $-65 \%$, and Fusarium culmorum - 53\% (Fig. 1).

\section{In vivo studies on the protective role of myxobacteria against the fungi pathogenic to pine seedlings}

Our studies have shown strong pathogenic activity of Rhizoctonia solani - strain $411.20 \%$ of seedlings 

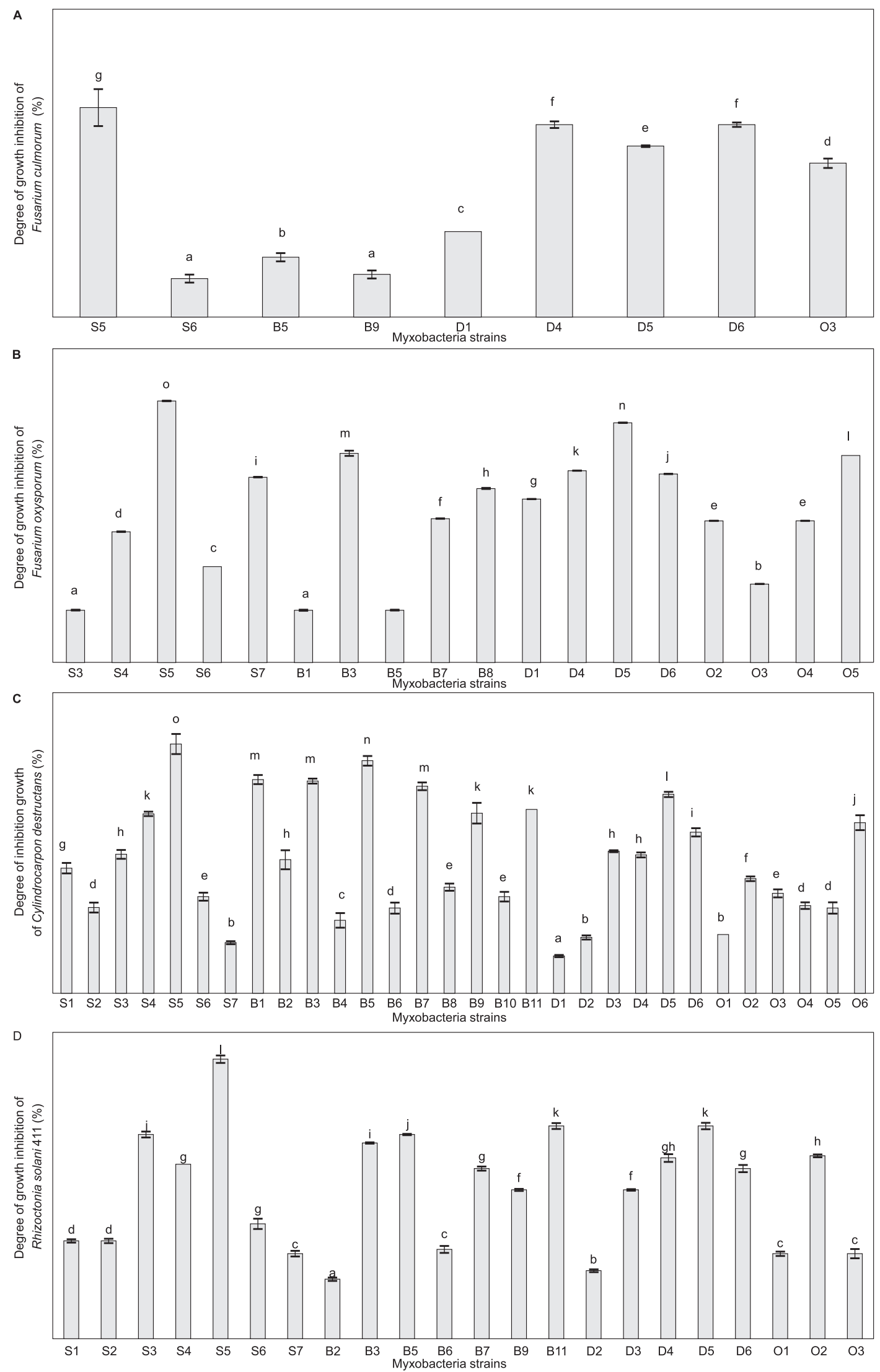

Fig. 1. Antagonism of myxobacteria strains towards pathogenic fungi

Explanations: S,B,D,O see Table 2; Among 30 strain of myxobacteria studied 9 inhibited growth of F. culmorum (A), 18 of F. oxysporum (B), all of them C. destructans (C) and 22 of $R$. solani (D) (average values \pm standard error, $n=3$; values marked with the same do not differ significantly at $\mathrm{p} \leq 0.05$ ) 
Table 3. Influence of pathogenic fungi and myxobacteria on the growth of pine seedlings [averages $(n=10) \pm$ standard deviation]

\begin{tabular}{|c|c|c|c|c|}
\hline Experimental combinations & $\begin{array}{l}\text { Root length }[\mathrm{mm}] \\
\text { (\% of control) }\end{array}$ & $\begin{array}{l}\text { Root dry weigh }[\mathrm{mg}] \\
\text { (\% of control) }\end{array}$ & $\begin{array}{c}\text { Stem length }[\mathrm{mm}] \\
\text { (\% of control) }\end{array}$ & $\begin{array}{c}\text { Stem dry weigh }[\mathrm{mg}] \\
\text { (\% of control) }\end{array}$ \\
\hline Control & $\begin{array}{l}169.3 \mathrm{ab} \\
\pm 19.46\end{array}$ & $60 b c \pm 20$ & $74 \mathrm{bc} \pm 14.71$ & $50 \mathrm{~b} \pm 20$ \\
\hline C. destructans & $\begin{array}{c}190.2 \mathrm{ab} \pm 33.78 \\
112.3\end{array}$ & $\begin{array}{c}70 \mathrm{bc} \pm 10 \\
116.7\end{array}$ & $\begin{array}{c}68.9 \mathrm{~b} \pm 14.81 \\
93.1\end{array}$ & $\begin{array}{c}60 \mathrm{~b} \pm 30 \\
120\end{array}$ \\
\hline F. oxysporum & $\begin{array}{c}145.4 \mathrm{ab} \pm 55.1 \\
85.9\end{array}$ & $\begin{array}{c}60 \mathrm{bc} \pm 20 \\
100\end{array}$ & $\begin{array}{c}65 \mathrm{~b} \pm 13.12 \\
87.8\end{array}$ & $\begin{array}{c}60 \mathrm{~b} \pm 30 \\
120\end{array}$ \\
\hline R. solani & $\begin{array}{c}121.8 \mathrm{a} \pm 70.66 \\
71.9\end{array}$ & $\begin{array}{c}20 \mathrm{a} \pm 10 \\
33.3^{*}\end{array}$ & $\begin{array}{c}51.2 \mathrm{a} \pm 28.18 \\
69.2 *\end{array}$ & $\begin{array}{c}20 \mathrm{a} \pm 10 \\
40^{*}\end{array}$ \\
\hline Myxococcus virescens (S5) & $\begin{array}{c}197 \mathrm{ab} \pm 44.23 \\
116.4\end{array}$ & $\begin{array}{c}90 c \pm 40 \\
150\end{array}$ & $\begin{array}{c}76 \mathrm{~b} \pm 28.36 \\
102.7\end{array}$ & $\begin{array}{c}60 \mathrm{~b} \pm 20 \\
120\end{array}$ \\
\hline M.virescens + C. destructans & $\begin{array}{c}202 \mathrm{~b} \pm 29.72 \\
119.3\end{array}$ & $\begin{array}{c}60 \mathrm{bc} \pm 20 \\
100\end{array}$ & $\begin{array}{c}82.7 \mathrm{~b} \pm 10.54 \\
111.8\end{array}$ & $\begin{array}{c}80 \mathrm{~b} \pm 30 \\
160\end{array}$ \\
\hline M. virescens + F. oxysporum & $\begin{array}{c}189.3 \mathrm{ab} \pm 30.77 \\
111.8\end{array}$ & $\begin{array}{c}40 \mathrm{~b} \pm 30 \\
66.7\end{array}$ & $\begin{array}{c}74.9 \mathrm{~b} \pm 10.14 \\
101.2\end{array}$ & $\begin{array}{c}90 \mathrm{~b} \pm 30 \\
180\end{array}$ \\
\hline M. virescens $+R$. solani & $\begin{array}{c}192.6 \mathrm{ab} \pm 73.84 \\
113.8\end{array}$ & $\begin{array}{c}60 \mathrm{bc} \pm 30 \\
100\end{array}$ & $\begin{array}{c}70 \mathrm{~b} \pm 14.53 \\
94.6\end{array}$ & $\begin{array}{c}60 \mathrm{~b} \pm 30 \\
120\end{array}$ \\
\hline Coralococcus exiguus (B5) & $\begin{array}{c}184 \mathrm{ab} \pm 69.43 \\
108.7\end{array}$ & $\begin{array}{c}70 \mathrm{bc} \pm 30 \\
116.7\end{array}$ & $\begin{array}{c}75 \mathrm{~b} \pm 12.47 \\
101.3\end{array}$ & $\begin{array}{c}60 \mathrm{~b} \pm 20 \\
120\end{array}$ \\
\hline C. exiguus + C. destructans & $\begin{array}{c}190 \mathrm{ab} \pm 15.54 \\
112.2\end{array}$ & $\begin{array}{c}60 \mathrm{bc} \pm 10 \\
100\end{array}$ & $\begin{array}{c}88 \mathrm{~b} \pm 6.23 \\
118.9\end{array}$ & $\begin{array}{c}80 \mathrm{~b} \pm 30 \\
160\end{array}$ \\
\hline C. exiguus + F. oxysporum & $\begin{array}{c}188 \mathrm{ab} \pm 24.52 \\
111\end{array}$ & $\begin{array}{c}70 b c \pm 20 \\
116.7\end{array}$ & $\begin{array}{c}73 \mathrm{~b} \pm 12.29 \\
98.6\end{array}$ & $\begin{array}{c}80 \mathrm{~b} \pm 20 \\
160\end{array}$ \\
\hline C.exiguus $+R$. solani & $\begin{array}{c}187 \mathrm{ab} \pm 36.76 \\
110.4\end{array}$ & $\begin{array}{c}80 \mathrm{bc} \pm 10 \\
133.3\end{array}$ & $\begin{array}{c}69 \mathrm{~b} \pm 11.50 \\
93.2\end{array}$ & $\begin{array}{c}70 \mathrm{~b} \pm 30 \\
140\end{array}$ \\
\hline Coralococcus exiguus (D4) & $\begin{array}{c}189.5 \mathrm{ab} \pm 26.61 \\
111.9\end{array}$ & $\begin{array}{c}80 c \pm 40 \\
133.3\end{array}$ & $\begin{array}{c}84.3 \mathrm{~b} \pm 19.84 \\
113.9\end{array}$ & $\begin{array}{c}90 \mathrm{~b} \pm 30 \\
180\end{array}$ \\
\hline C. exiguus + C. destructans & $\begin{array}{c}185.5 \mathrm{ab} \pm 71.10 \\
109.6\end{array}$ & $\begin{array}{c}50 \mathrm{bc} \pm 20 \\
83.3\end{array}$ & $\begin{array}{c}65 \mathrm{~b} \pm 5.27 \\
87.8\end{array}$ & $\begin{array}{c}70 \mathrm{~b} \pm 50 \\
140\end{array}$ \\
\hline C. exiguus + F. oxysporum & $\begin{array}{c}171.2 \mathrm{ab} \pm 74.36 \\
101.1\end{array}$ & $\begin{array}{c}60 \mathrm{bc} \pm 20 \\
100\end{array}$ & $\begin{array}{c}78 \mathrm{~b} \pm 7.89 \\
105.4\end{array}$ & $\begin{array}{c}80 \mathrm{~b} \pm 20 \\
160\end{array}$ \\
\hline C. exiguus $+R$. solani & $\begin{array}{c}181 \mathrm{ab} \pm 34.71 \\
106.9\end{array}$ & $\begin{array}{c}60 \mathrm{bc} \pm 20 \\
100\end{array}$ & $\begin{array}{c}78 \mathrm{~b} \pm 7.53 \\
105.4\end{array}$ & $\begin{array}{c}80 \mathrm{~b} \pm 30 \\
160\end{array}$ \\
\hline
\end{tabular}

Explanations: values in the same column, marked with the same letter do not differ significantly ( $\mathrm{p} \leq 0.05)$, Newman - Keuls' multiple range test.

${ }^{*}$ - significant inhibition, ${ }^{* *}$ - significant stimulation

tested were dead; in the remaining ones a strong growth inhibition was observed as compared to the uninoculated (control). However, no significant pathogenic effect towards pine seedlings was noted in Cylindrocarpon destructans and Fusarium oxysporum. Therefore, we cannot conclude about any protective action of myxobacteria against these well known pathogens of pine seedlings. Moreover, we observed that inoculation of seedlings with fungi and myxobacteria exerted a stimulatory action both on development of seedling root and shoot - in case of all the fungi studied. Myxobacteria suppressed pathogenic action of $R$. solani, strain 411 (Table 3).

Reisolation and identification of myxobacteria from the rhizosphere of the pine seedlings has confirmed the presence of these bacteria in the above mentioned habitat.

\section{Proteolytic activity of myxobacteria}

Myxobacteria studied by us produced proteolytic enzymes. In most post-culture liquids of the strains studied acid (in 22 strains) and neutral (in 19 strains) proteinases were detected (Fig. 2). These enzymes were more frequently produced in presence of sodium caseinate than yeast extract. Proteinases were not detected in cellular disintegrates. The highest activity of acid proteinases (122.1450 mU) was noted in the strain belonging to the species Corallococcus exiguus, and the lowest in the Corallococus coralloides $(0.8570 \mathrm{mU})$ (Fig. 2A). The highest activity of neutral proteinases in the presence of sodium caseinate was noted in post-culture liquids of Polyangium fumosum $(71.8111 \mathrm{mU})$, and the lowest one - in Myxococcus fulvus $(1.5364 \mathrm{mU})$. Polyangium fumosum had also the highest activity of neutral proteinases at the presence of yeast extract $(31.4337 \mathrm{mU})$, and the lowest 

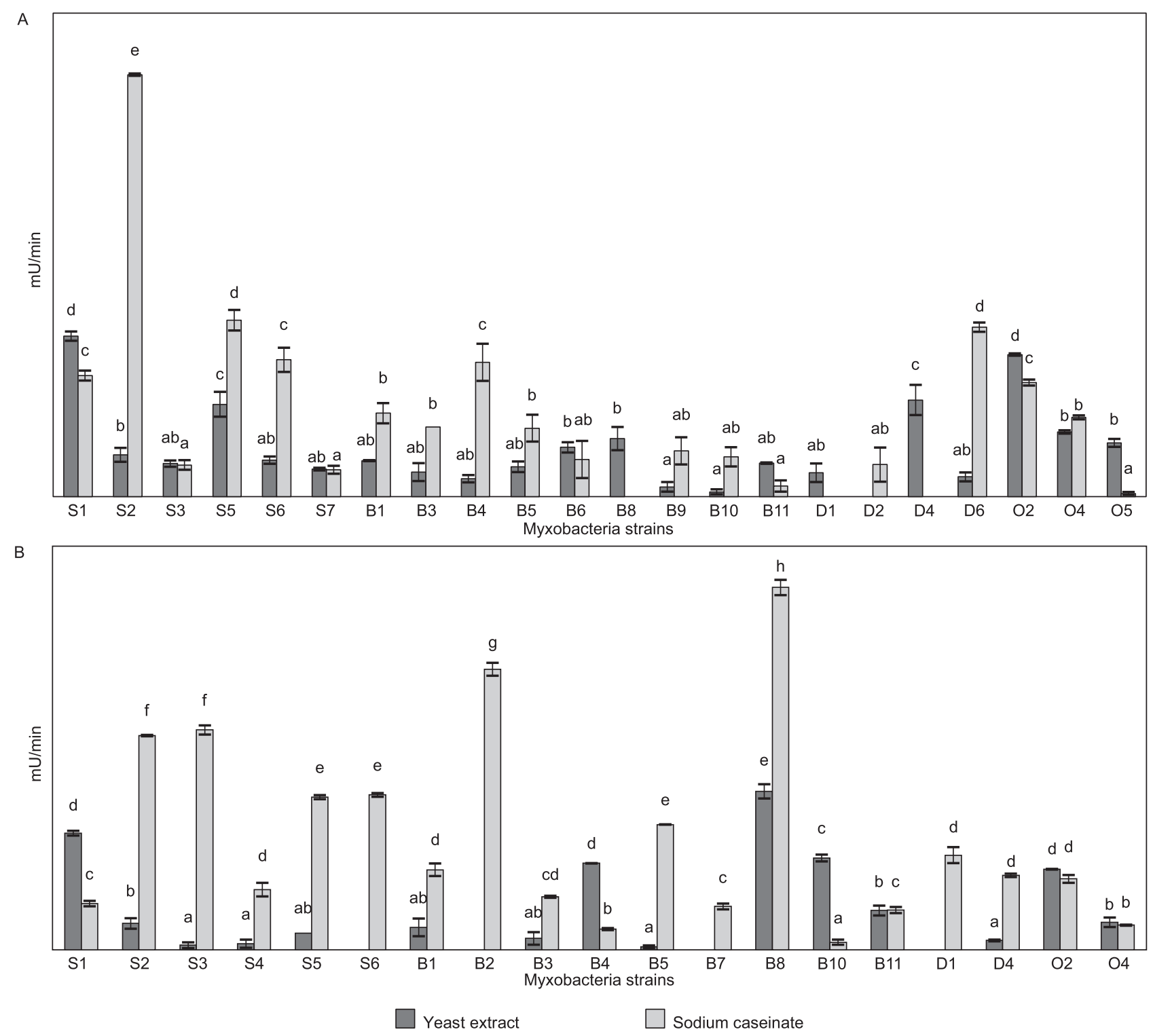

Fig. 2. Proteolytic activity of myxobacteria strains (A: acidic proteases, B: neutral proteases)

Explanation: S,B,D,O see Table 2 (average values \pm standard error, $n=9$; values marked with the same do not differ significantly at $\mathrm{p} \leq 0.05)$

activity of the same enzymes at the presence of yeast extract was observed in post-culture liquids of Corallococcus exiguus (0.6151 mU) (Fig. 2B). Various myxobacterial strains of the same species exhibited different proteolytic activity. It provides evidence that the proteolytic activity is a strain dependent property.

\section{Chitinolytic activity}

In our experiments, none of the myxobacterial strains studied produced chitinases.

\section{Siderophore synthesis}

Out of 30 myxobacterial strains studied, 16 of them $(53 \%)$ produced siderophores. The largest number of siderophore producers was detected in the soil under Scots pine (5 from among 7 strains $71 \%)$ and the lowest one in the soil under alder (1 from among 6 strains - 17\%) (Fig. 3).

\section{Discussion}

The results of present work confirmed our hypothesis that myxobacteria isolated from acidic soil may be a biocontrol agent of some pathogenic fungi such as Rhizoctonia solani.

It is well known since long ago that myxobacteria can lyse other microorganisms. The range of microorganisms sensitive to myxobacterial lysis is wide and comprises eubacteria, actinomycetes, yeasts and 

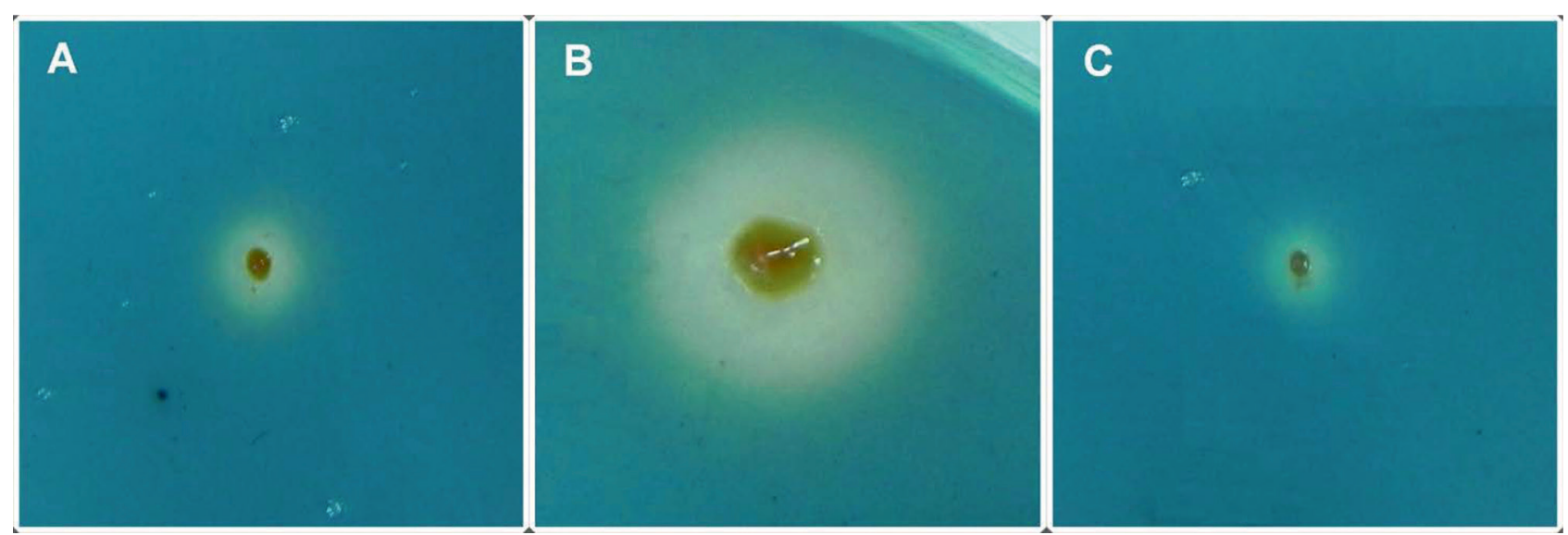

Fig. 3. Synthesis of siderophores by Myxococcus virescens S1(A), D6 (B) and Caralococcus exiguus B1 (C) (agar CAS)

other fungi. According to Singh and Yadaya (1976), active strains belong mainly to the genus Myxococcus. Hocking and Cook (1972) and Bull et al. (2002) reported a lytic activity of soil myxobacteria towards some fungal plant pathogens and were capable of suppressing diseases of forest trees seedlings. Many researchers deal with relationships between bacteria and fungi in soil, but studies considering interactions between myxobacteria and plant pathogenic fungi are rare. Despite the fact that myxobacteria are abundant in many types of soils and comprise about $1 \%$ of soil bacteria, up to now a little attention was paid on identification of forest soils myxobacteria, considering that habitats of this kind are not preferably inhabited by these bacteria (Dawid 2000; Shimkets et al. 2006). Methods of isolation of myxobacteria from soil are rather sophisticated. It is difficult to obtain and maintain any pure strain cultures. The above mentioned procedures are different from those commonly used for isolation of other soil bacteria (Reichenbach and Höfle 1993). The occurrence of myxobacteria is significantly affected by soil $\mathrm{pH}$. Majority of them grows at $\mathrm{pH}$ 6.8-7.8. However, the cellulolytic myxobacteria can inhabit biotopes of lower pH (5.8-6.4) (Reichenbach 2005). In our studies, we have isolated myxobacteria both from the acidic forest soil $(\mathrm{pH} \mathrm{4.22-5.05)}$ and from the alkaline non-forest soils ( $\mathrm{pH}$ 7.94), for comparison. Strains isolated from the alkaline soil comprised over half of those which have been obtained. Reichenbach (1993) stated that from the 0.5-1 gram of fertile soil can be isolated 5-10 species of myxobacteria. In our studies in $0.1 \mathrm{~g}$ soil sample we have detected 1-2 species of these bacteria. In forest soils of the middle Europe, Dawid (2000) noticed the following species of myxobacteria: Archangium gephyra Jahn, Corallococcus coralloides (Thaxter) Reichenbach, Cystobacter fuscus Schroeter, Myxococcus fulvus (Cohn) Jahn, M. virescens, $M$. xanthus Beebe as well as species of the genus Polyangium. Michałowska (2009) demonstrated that in forest soils of central Poland, cellulolytic species Polyangium compositum Thaxter and Sorangium cellulosum were predominant. Myxococcus fulvus and Corallococcus corraloides were detected. Myxobacteria isolated in our studies were the members of eight taxons with Corallococcus exiguus as the most frequent species $(40.98 \%)$. The highest species diversity in soils from under birch and willow (6 species) was observed, the lowest one - in soils from under oak and alder (2 species). A significant effect on myxobacterial diversity could exert tree root exudates, which act selectively on rhizosphere microorganisms. Myxobacteria are known as micropredators, as they attack other microorganisms in their natural habitats, releasing apart from antibiotic compounds also enzymes breaking down any cell biopolymers and causing lysis of prey cells. Enzymatic activity of myxobacteria undoubtedly can affect the qualitative-quantitative regulation of microbial population (Dworkin 2007). It is assumed that the myxobacterial predatory nature can be used for biological control of many pathogens (Dawid 2000; Rashidan and Bird 2001). In the lytic effects of myxobacteria towards fungi, chitinases and proteases are very important. The importance of bacterial chitinases in antifungal activity and in biological control of pathogens was studied by many authors (Broglie et al. 1991; Vierheilig et al. 1993; Mahadavan and Crawford 1997). Also in our studies it was assumed to demonstrate any contribution of chitinases produced by myxobacteria in the biological protection of pine seedlings against fungal root pathogens. However, our studies in vitro have not shown any chitinolytic activity in all the strains studied. A survey of literature indicates, that chitinolytic activity is rare among myxobacteria (Reichenbach 2005). It seems that any lack of chitinolytic activity in myxobacteria can be a factor, which eliminates them from the group of organisms biocontrolling the fungal pathogens. However, the experiments carried out by Barea et al. (1998) as well as in present work have shown that the fungal growth can be inhibited also by strains unable to synthesis of 
chitinases. Considering the enzymatic activity, also proteinases may participate in the above mentioned interactions (Rodziewicz and Sobieszczański 1988). Strain B2-S1 of Myxococcus virescens studied by Gnosspelius (1978) synthesized three extracellular proteinases, which can take part in the cell wall degradation of attacked microorganisms, releasing assimilable peptides and amino acids (Rosenberg and Varon 1984). Our results confirm reports of other authors about the common production of proteinases by myxobacteria (Gnosspelius 1978; Rosenberg and Varon 1984; Reichenbach 2005). The myxobacterial strains studied by us produced both acidic and neutral proteinases. However, the activity of these enzymes, under the conditions of our experiments was low ( $\mathrm{mU} / \mathrm{min}$ ). Plants are able to assimilate iron via microbial siderophores, biosynthesized by saprophytic root colonizing bacteria (Sharma et al. 2003; Vansuyt et al. 2007). They deprive pathogens of the iron required for their growth and pathogenesis. The myxobacteria studied in our work were able to produce siderophores. It appears from the results of studies by Homma (1984) and Bull et al. (2002), that myxobacteria can inhibit the growth and development of the following plant pathogens: Cochliobolus miyabeanus (Ito et Kuribayashi) Dreshsler, Cylindrocarpon sp., Fusarium oxysporum, Phytophthora capsici Leonian, Pythium intermedium de Bary, Rhizoctonia solani, Verticillium albo-atrum Reinke and Berth, V. dahliae Kleb. The isolates of Rhizoctonia solani were particularly sensitive on the inhibitory action of myxobacteria. Similarly, our studies have shown high sensitivity of $R$. solani in presence of myxobacteria in a common culture. However, the myxobacterial strains studied by us exerted the strongest inhibitory action on C. destructans; the most resistant fungus was F. culmorum. The above profile of our studies, made possible selecting three strains of myxobacteria, belonging to Myxococcus virescens and Corallococcus exiguus, having a strong antagonism towards pathogenic fungi and using them in the antagonism studies in vivo. These bacteria protected the roots of pine seedlings against the fungal pathogen $R$. solani. It was not possible to show any protective potential of selected myxobacteria against C. destructans and F. oxysporum, because under the control conditions (without myxobacteria) they did not show any pathogenicity towards pine seedlings. The pathogenicity in many fungi is not a permanent feature. A multiple passage of isolates under laboratory conditions may affect on loss of their pathogenicity. Besides, some fungi are facultative pathogens, e.g. C. destructans, which usually defeats the weak seedlings. The effective colonization of rhizosphere is a prerequisite of any biological control action of microorganisms against the plant root pathogens (Yuan and Crawford 1995). In our studies, the previously introduced myxobacteria were reisolated, which points out their survivability in this environment. Many reports show the great possibilities of use of biological control as an alternative for chemical plant protection agents, but the chemical plant protection is to be still for a long time an important part of the plant protection programs (Paul and Clark 1996; Bressan 2003).

\section{Acknowledgements}

This research has been financed by a grant from Polish Ministry of Science and Higher Education (Grant No. NN309427438).

\section{References}

Alexander D.B., Zuberer D.A. 1991. Use of chrome azurol $\mathrm{S}$ reagents to evaluate siderophore production by rhizosphere bacteria. Biology and Fertility of Soils 12: 39-45.

Behrens J., Flossdorf J., Reichenbach H. 1976. Base composition of deoxyribonucleic acid from Nannocystis exedens (Myxobacterales). International Journal of Systematic Bacteriology 26: 561-562.

Bressan W. 2003. Biological control of maize seed pathogenic fungi by use of actinomycetes. BioControl 48: 233-240.

Broglie K., Chet I., Holliday M., Cressman R., Biddle P., Knowlton S., Mauvius C.J., Broglie R. 1991. Transgenic plants with enhanced resistance to the fungal pathogen Rhizoctonia solani. Science 254: 1194-1197.

Bull C.T., Shetty K.G., Subbarao K.V. 2002. Interactions between myxobacteria, plant pathogenic fungi, and biocontrol agents. Plant Disease 86: 889-896.

Chet I., Inbar J. 1994. Biological control of fungal pathogens. Applied Biochemistry and Biotechnology 48: 37-43.

Dawid W. 2000. Biology and global distribution of myxobacteria in soils. FEMS Microbiology Reviews 24: 403-427.

Dworkin M. 2007. Lingering puzzles about myxobacteria. Microbe 2: 18-24.

Hazen G.G., Hause J.A., Hubicki J.A. 1965. An automated system for the quantitative determination of proteolytic enzymes using azocasein. Annals of the New York Academy Science 130: 761-768.

Hocking D., Cook F.D. 1972. Myxobacteria exert partial control of damping-off and root disease in container-grown tree seedlings. Canadian Journal of Microbiology 18: 1557-1560.

Homma Y. 1984. Perforation and lysis of hyphae of Rhizoctonia solani and conidia of Cochliobolus miya- 
beanus by soil myxobacteria. Phytopathology 74 :1234-1239.

Kerk D., Uhrig R.G., Moorhead G.B. 2013. Bacterial-like PPP protein phosphatases: novel sequence alterations in pathogenic eukaryotes and peculiar features of bacterial sequence similarity. Plant Signaling \& Behavior 8: e27365.

Kim O.S., Cho Y.J., Lee K., Yoon S.H., Kim M., Na H., Park S.C., Jeon Y.S., Lee J.H., Yi H., Won S., Chun J. 2012. Introducing EzTaxon-e: a prokaryotic 16S rRNA gene sequence database with phylotypes that represent uncultured species. International Journal of Systematic and Evolutionary Microbiology 62: 716-721.

Kloepper J.W., Leong J., Teintze M., Schroth M.N. 1980. Pseudomonas siderophores: a mechanism explaining disease-suppressive soils. Current Microbiology 4: 317-320.

Lang E., Stackebrandt E. 2009. Emended descriptions of the genera Myxococcus and Corallococcus, typification of the species Myxococcus stipitatus and Myxococcus macrosporus and a proposal that they be represented by neotype strains. Request for an Opinion. International Journal of Systematic and Evolutionary Microbiology 59: 2122-2128.

Lingappa Y., Lockwood J.L. 1962. Chitin media for selective isolation and culture of actinomycetes. Phytopathology 52: 317-323.

Mahadevan B., Crawford D.L. 1997. Properties of the chitinase of the antifungal biocontrol agent Streptomyces lydicus WYEC108. Enzyme and Microbial Techology 20: 489-493.

Michałowska M.A. 2009. The occurrence and characterization of bacteria of the Myxococcales order isolated from selected types of Polish soils. Ph. D. Thesis, Autonomous Department of Microorganisms' Biology, Faculty of Agriculture and Biology, Warsaw University of Life Sciences - SGGW, Warsaw, Poland. (In Polish with English summary)

Morgan A.D., MacLean R.C., Hillesland K.L., Velicer G.J. 2010. Comparative analysis of myxococcus predation on soil bacteria. Applied Environmental Microbiology 76: 6920-6927.

Paul E.A., Clark F.E. 1996. Soil Microbiology and Biochemistry, 2nd edn. Academic Press, San Diego.

Raheman F., Deshmukh S., Ingle A., Gade A., Rai M. 2011. Silver nanoparticles: novel antimicrobial agent synthesized from an endophytic fungus Pestalotia sp. isolated from leaves of Syzygium cumini (L). Nano Biomedicine and Engineering 3: 174-178.

Rai M., Yadav A., Gade A. 2009. Silver nanoparticles as a new generation of antimicrobials. Biotechnology Advances 27: 76-83.

Rashidan K.K., Bird D.F. 2001. Role of predatory bacteria in the termination of a cyanobacterial bloom. Microbial Ecology 41: 97-105.
Reichenbach H. 1993. Biology of the myxobacteria: ecology and taxonomy. In: Myxobacteria II. Dworkin M., Kaiser D. (eds.). American Society for Microbiology, Washington, pp. 13-62.

Reichenbach H. 1999. The ecology of the myxobacteria. Environmental Microbiolgy 1: 15-21.

Reichenbach H. 2005. Order Myxococcales. In: Bergey's Manual of Systematic Bacteriology, 2nd edn. Brenner D.J., Krieg N.R., Staley J.T. (eds.). Springer, pp. 1059-1144.

Reichenbach H., Dworkin M. 1981. The order Myxobacterales. In: The Prokaryotes, 1st edn. Starr K.P., Stolp H., Trüper H.G., Balows A., Schlegel H.G. (eds.). Springer-Verlag, Berlin, pp. 328-355.

Reichenbach H., Höfle G. 1993. Biologically active secondary metabolites from myxobacteria. Biotechnology Advances 11: 219-277.

Rodina A. 1968. Microbiological methods of water examination. Państwowe Wydawnictwo Rolnicze i Leśne, Warszawa. (In Polish)

Rodziewicz A., Sobieszczański J. 1988. Extracellular proteinases of microorganisms. Postępy Mikrobiologii 27: 55-74. (In Polish)

Rosenberg E., Varon M. 1984. Antibiotics and lytic enzymes. In: Myxobacteria. Development and Cell Interactions. Rosenberg E. (ed.). Springer-Verlag, New York, pp. 109-125.

Sharma A., Johri B.N., Sharma A.K., Glick B.R. 2003. Plant growth-promoting bacterium Pseudomonas sp. strain GRP3 influences iron acquisition in mung bean (Vigna radiata L. Wilzeck). Soil Biology and Biochemistry 35: 887-894.

Shimkets L.J., Dworkin M., Reichenbach H. 2006. The myxobacteria. In: The Prokaryotes, 3nd. Dworkin M., Falkow S., Rosenberg E., Schleifer K.H., Stackerbrandt E. (eds.). Springer-Verlag, Heidelberg, pp. 31-115.

Singh B.N., Yadava J.N.S. 1976. Fructification and antagonistic effect of myxobacteria on eubacteria: lytic effect and fruiting body formation of Myxococcus, Chondrococcus and Angiococcus spp. Indian Journal of Experimental Biology 14: 68-70.

Sunkar S., Nachiyar C.V. 2012. Biogenesis of antibacterial silver nanoparticles using the endophytic bacterium Bacillus cereus isolated from Garcinia xanthochymus. Asian Pacific Journal of Tropical Biomedicine 2: 953-959.

Vansuyt G., Robin A., Briat J.F., Curie C., Lemanceau P. 2007. Iron acquisition from Fe-pyoverdine by Arabidopsis thaliana. Molecular Plant-Microbe Interactions 20: 441-447.

Vierheilig H., Alt M., Neuhaus J.-M., Boller T., Wiemken A. 1993. Colonization of transgenic Nicotiana sylvestris plants, expressing different forms of Nicotiana tabacum chitinase, by the root pathogen Rhizoctonia solani and by the mycorrhizal symbiont 
Glomus mosseae. Molecular Plant-Microbe Interactions 6: 261-264.

Whooley M.A., O'Callaghan J.A., McLoughlin A.J. 1983. Effect of substrate on the regulation of exoprotease production by Pseudomonas aeruginosa ATCC 10145. Journal General Microbiology 129: 981-988.

Wrótniak-Drzewiecka W., Gaikwad S., Laskowski D., Dahm H., Niedojadło J., Gade A., Rai M. 2014.
Novel approach towards synthesis of silver nanoparticles from Myxococcus virescens and their lethality on pathogenic bacterial cells. Austin Journal of Biotechnology and Bioengineering 1: 7.

Yuan W.M., Crawford D.L. 1995. Characterization of Streptomyces lydicus WYEC108 as a potential biocontrol agent against fungal root and seed rots. Applied and Environmental Microbiology 61: 3119-3128. 